\title{
Cold Injury and Flash Flood Damage in Boro Rice Cultivation in Bangladesh: A Review
}

\author{
M M Rashid ${ }^{1^{*}}$ and R Yasmeen ${ }^{1}$
}

\begin{abstract}
Increasing population with decreasing resources and increasing climate vulnerability appeared as the great challenges to sustain food security of Bangladesh. Cold stress adversely affects growth and productivity of rice (Oryza sativa L.). Systematic studies have been carried out to improve understanding on rice cold tolerance. Two adverse conditions, such as low temperature stress at reproductive stages and flash flood at maturity affect the Boro rice in the haor areas of Bangladesh. Any deviation of these two phenomena is enough to cause disaster in haor areas. Here, we summarized different types of cold injury, rice cold injury scenario and cold tolerant rice varieties/genotypes available in different countries. Moreover, we discussed on rice cold tolerant barrier and flash flood risk in Boro rice cultivation at haor areas of Bangladesh. Based on the authors' own research and available data, the concept of overcoming cold and flash flood damage was proposed. According to this concept there were distinguished possible ways how to improve cold tolerance and flash flood problem in Boro rice cultivation in Bangladesh.
\end{abstract}

Key words: Boro season, cold injury, flash flood, critical temperature

\section{INTRODUCTION}

Rice (Oryza sativa L.) is one of the most important staple crops and extensively cultivated by more than half of the world's farmers (Fairhurst and Dobermann, 2002; Shelton et al., 2002). More than $90 \%$ of the worlds' rice is grown in Asia, where almost $60 \%$ of the worlds' population lives (Subudhi et al., 2006). Rice is not only a staple food but also one of the most important cereal crops in Bangladesh which plays a significant role in socio-economy of the country. Enhancing rice production is the key to ensure food security. Rice security is synonymous to food security in many rice growing countries like Bangladesh (Brolley, 2015), which is an important issue for determining social and political stability (Nath, 2015). Rice production in Bangladesh has been increased from 10.79 million tons in 1970 to about 34.86 million tons in 2014-15 (AIS, 2016). Now, Bangladesh is entering gradually into the rice export regime (BER, 2015). However, the future challenge is to maintain the current surplus of rice in order to sustain rice security of the country. Bangladesh will need to produce more food grain with its limited resources to feed her huge population in the coming days.

Various abiotic stresses reduce rice yield greatly (Vij and Tyagi, 2007) which challenge the future food security and are huge threat for agriculture (Kumari et al., 2009). Minimizing yield loss is a major concern to cope with the increasing food demands (Mahajan and Tuteja, 2005). Low temperature induced rice yield loss is a worldwide problem (Peyman and Hashem, 2010), but it is a major constraint to rice production in mountainous regions of the tropics and in the temperate rice-growing zones of the world (Xie et al., 2012). Northern districts of Bangladesh are cold prone areas of the country. Boro rice is greatly affected by cold during crop establishment and reproductive stage. Seedling mortality sometimes goes up to $90 \%$ especially in northern part of the country. In recent years, more than 2.0 million hectares of rice crop in northern and north-eastern parts of Bangladesh have been affected by severe cold spell causing partial to total loss. In the haor areas of Bangladesh, early planted. Boro

${ }^{1}$ Plant Physiology Division, Bangladesh Rice Research Institute (BRRI), Gazipur, Bangladesh. *Corresponding authors E-mail: mrashidbrri@gmail.com 
rice has to face cold stress at the reproductive stages (PI to flowering). Spikelet sterility is observed in this early planted Boro rice, if mean temperature in mid-February to mid-March prevails below $20^{\circ} \mathrm{C}$ for more than 5-6 days at reproductive stage of the plant (Biswas et al., 2011). The farmers of the haor areas consider their Boro crop as a chance harvest as they might have to encounter the flash flood every few years at maturity stage (Biswas et al., 2008). Recent loss due to early flash flood in Boro 2017 at the haor area is irreparable. We have to find out a way to cope with the situation. The most important thing to mitigate this issue is cultivation of short duration cold tolerant varieties in the haor areas. Since inception in 1971, the scientists in Bangladesh Rice Research Institute are giving their efforts to develop cold tolerant rice varieties. A little success was also made possible with the development of a cold tolerant variety BRRI dhan36, but its efficiency is not praiseworthy in present level of cold stress. In this paper, we have focused on rice cold injury status and cold tolerant rice genotypes in different countries, ways to improve cold tolerance of rice plants and present cold management practices. Moreover, we also discuss on risk reduction in Boro rice cultivation in haor areas of Bangladesh.

\section{REVIEW}

\section{Low temperature injury in rice}

Rice is a thermophilous crop due to its origin in tropical and subtropical regions (Basuchaudhury, 2014). Optimum temperature for rice growing is 25 to $35^{\circ} \mathrm{C}$ for indica and 20 to $33^{\circ} \mathrm{C}$ for japonica (Yoshida, 1981). It is more sensitive to cold stress than the other cereal crops such as wheat (Triticum aestivum L) and barley (Hordeum vulgare L). Low temperature can damage the plant during any development stage such as germination, seedling, vegetative, reproductive and maturity (Andaya and Mackill, 2003; Xu et al., 2008; Ye et al., 2009). The most common symptoms of cold temperature damage at the germination stage are delayed and lower percentage of germination (Cruz and Milach, 2004). At the vegetative stage, chilling damage is expressed through yellowing of the leaves, decreased tillering, lower stature, less biomass production and increased growth duration of the plants (Alvarado and Hernaiz, 2007). Rice is highly susceptible to low temperature at reproductive stage (Yoshida, 1981; Cruz et al., 2006). Low temperature at this stage causes abnormalities at anthesis such as cessation of anther development, non-ripening of pollen grains, non-emergence of anthers from spikelets, partial or no anther dehiscence, little or no pollen shedding and failure of pollen to germinate after reaching stigmas (Cruz et al., 2013).

Cold stress also causes many types of phenotypic damage, such as delayed heading, incomplete panicle exertion and degeneration of spikelet (Shimono et al., 2007; Ye et al., 2009). But spikelet sterility is the most common symptom of injury when rice plants experience cold temperature at the reproductive stage (Jacobs and Pearson, 1994; Cruz et al., 2006). Spikelet sterility results from pollen abortion due to cold injury during microsporogenesis, when pollen grains are being formed at the booting stage (Mackill et al., 1996). The level of damage largely depends on the development stage of rice plants and intensity of the cold event (Jacobs and Pearson, 1994). The young microspore stage is the most susceptible stage to chilling injury that causes male sterility (Yoshida, 1981). This stage occurs approximately 10 to 12 days prior to heading of rice (Heenan, 1984). It is reported that spikelet sterility increases with the increase of low temperature duration at the young microspore stage (Heenan, 1984). Other experiments indicate that 14-7 days before heading, commonly referred to as the booting stage, is considered the most sensitive stage to low temperatures followed by heading or flowering (Yoshida, 1981). Cold stress causes catastrophic yield loss by affecting rice plants' biological functions and overall metabolism negatively. Smillie et al. (1988) showed that photosynthesis is impaired at low temperature which reduces growth and yield as there is less carbohydrate available for grain production. 
Other studies showed that low temperatures cause delayed and incomplete grain maturation (Ye et al., 2009) that affect adversely on grain yield and quality (Jena et al., 2012).

\section{Critical low temperature}

Ambient temperature below $20^{\circ} \mathrm{C}$ is normally considered as the critical low temperature for rice. The critical temperatures vary from one growth stage to another of the plant (Table 1). But it also differs according to variety, duration of critical temperature, growing conditions and diurnal changes (Farrell et al., 2006). Yoshida (1981) showed that rice plants have a lower threshold temperature $\left(10-13^{\circ} \mathrm{C}\right)$ for cold damage during the early stages of development (germination and vegetative), while threshold temperature for damage is higher $\left(18-20^{\circ} \mathrm{C}\right)$ at the reproductive stage. Rice plant subjecting to below $20^{\circ} \mathrm{C}$ at about the reduction division stage of the pollen mother cells usually induces a high percentage of spikelet sterility (Yoshida, 1981). Satake (1976) reported that the thresholds air temperature capable of inducing cold damage at the reproductive stage are $20^{\circ} \mathrm{C}$ for coldsensitive varieties and $15^{\circ} \mathrm{C}$ for cold-tolerant varieties. Crop damage through spikelet sterility occurs if the air temperature prevails below critical low temperature for three days at reproductive stage, but damage is severe if it prevails for more than 5-6 days (BRRI, 2017).
Temperatures as low as $12^{\circ} \mathrm{C}$ will not induce sterility if they last for only two days, but it will induce about $100 \%$ sterility if they last for six days (Yoshida, 1981). Farrell et al. (2006) reported the critical night temperature capable of inducing cold damage ranges from 13 to $15^{\circ} \mathrm{C}$. Biswas et al. (2011) suggested night temperature of $12-13^{\circ} \mathrm{C}$ and day temperature of $28-29^{\circ} \mathrm{C}$ as critical temperature during reproductive stage of rice plant, as these levels reduced $50 \%$ of the original yield level. Although low temperatureinduced sterility is normally attributed to low night temperatures, high day temperatures appear to alleviate the effects of low night temperatures (Yoshida, 1981).

Rice cold injury scenario in different countries Rice cold injury at high latitude and altitude areas were well documented in Japan, Korea, China, Nepal, Bhutan, Australia and other countries (Shimono et al., 2007; Jena et al., 2012). Sthapit (1992) reported that around $26 \%$ of rice land of Nepal falls within the temperate region [1000-2000 m above sea level (asl)] and chilling injury is a major constraint of rice production here. The degree of yield loss is quite high at $1300 \mathrm{~m}$ above sea level showing high degree of sterility and panicle degeneration (Sthapit, 1992). Gautam and Shrestha (2012) reported that two main types of cold damage occur in Nepal namely delayed-type and sterile-type.

Table 1. Response of the rice plant to varying temperatures at different growth stages ${ }^{\text {a }}$.

\begin{tabular}{lccc}
\hline Growth stage & \multicolumn{3}{c}{${\text { Critical temperature }\left({ }^{\circ} \mathrm{C}\right)}^{\text {Optimum }}$} \\
\cline { 2 - 4 } & Low & High & $20-35$ \\
\hline Germination & 10 & 45 & $25-30$ \\
Seedling emergence and establishment & $12-13$ & 35 & $25-28$ \\
Rooting & 16 & 35 & 31 \\
Leaf elongation & $7-12$ & 45 & $25-31$ \\
Tillering & $9-16$ & 33 & - \\
Initiation of panicle primordia & 15 & - & - \\
& & & $30-33$ \\
Panicle differentiation & $15-20$ & 38 & $20-25$ \\
Anthesis & 22 & 35 & 30 \\
Ripening & $12-18$ & & \\
\hline
\end{tabular}

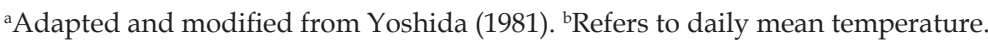


The delayed type of cold damage is prevalent at altitudes between 300 and $1300 \mathrm{~m}$ above sea level (Sthapit, 1992; Gautam and Shrestha, 2012). The sterile-type cold damage in rice is usually found at $1300 \mathrm{~m}$ above sea level. At Lumlee, (1400 m asl) in Nepal mean air temperature falls below $20^{\circ} \mathrm{C}$ at the beginning of the reproductive stage. Sterile type of cold damage is a serious problem in this type of environment (Sthapit, 1992; Gautam and Shrestha, 2012). At Chhomrong in Nepal, mean air temperature is low throughout the growing season (Sthapit, 1992). In the Jumla Valley of Nepal, mean air temperature above the critical temperature $\left(20^{\circ} \mathrm{C}\right)$ remain only for six weeks in a year from the second week of June to mid August (Sthapit, 1992). The sterile-type cold damage causes incomplete fertilization due to non-viable pollen and failure in anthesis and increases in the number of sterile spikelet (Gautam and Shrestha, 2012; Gautam et al., 2013).

At the higher elevations of Bhutan, air temperatures during seedling growth (MarchApril) and at later ripening stage (OctoberNovember) remain around $15^{\circ} \mathrm{C}$ or below making the rice varieties highly susceptible to cold injury (Ghimiray, 2012). The temperatures begin to drop sharply from September. If transplanting is delayed, the crop encounters a cold injury at flowering and ripening stages during October-November that cause spikelet sterility (Ghimiray et al., 2013). In India, cold rice is grown in about one million ha of hill regions in Jammu and Kashmir and north eastern hill states accounting $2.3 \%$ of total area under rice (Singh et al., 2017). Cold is also an important abiotic constraint at Telangana in India, where low temperature of $8^{\circ} \mathrm{C}$ to $13^{\circ} \mathrm{C}$ prevails from December to the first fortnight of February (Neelima et al., 2015).

Low temperatures seriously damaged the Korean rice crop (Lee, 2001). In the northern mountainous regions, the rice plants suffer from low temperatures at any stage between germination and maturity. In years of extreme low temperatures, all rice-growing areas are susceptible to cold at the reproductive stage (Lee, 2001). Early rice suffered from chilling damage mainly at seedling stage (February-
March) in southeastern China, while late rice at reproductive stage (October-November) in northeastern, eastern and southwestern China (Dingyuan and Liqun, 1989; Tao et al., 2012). In Japan, air temperature gradually increases from planting of rice (April-May) and reached to the highest peak in August, then it declines to below critical temperature in September and October when rice crops are at flowering or ripening stages. Rice cold damage is a nationwide problem in Japan, but it is a serious problem in the northern regions of Hokkaido and Tohoku areas (Nakagomi, 2013). In Australia, low temperature during late January to early February at reproductive stage disturbs development of pollen grains that causes spikelet sterility (Satake et al., 1987; Reinke et al., 2012).

\section{Variety released worldwide}

Many species of tropical or subtropical origin are affected by cold temperatures and exhibit various symptoms of chilling injury such as chlorosis, necrosis or growth retardation. In contrast, chilling-tolerant species are able to grow at such low temperatures (Sanghera et al., 2011). Various rice germplasm accessions exhibit considerable variation in the extent of cold tolerance (Kim and Tai, 2011; Sharifi, 2010). The high mountains of Nepal are important for cold tolerant genes of rice. The famous Jumli Marsi variety of rice is being grown at the highest elevation, up to 3000 meters above sea level (asl) in Chhumchaur, Jumla of Nepal. Gautam and Shrestha, (2012) reported that Chhomrong dhan (rice), Machhapuchre-3 and Palung-2 have been released for cool temperate high hills areas (1,300-2,000 m asl) of Nepal; while Chandannath-1 and Chandannath-3 for Jumla valley $(2,300 \mathrm{~m}$ asl) and similar areas. On the other hand, Tainan-1, Chainan-2, Chainung-242, Taichung-176, Himali, Kanchan, Khumal-2, Khumal-3, Khumal-4, Khumal-5, Khumal-6, Khumal-7, Khumal-8, Khumal-9 and Manjushree 2 have been released for foot hills to mid hills of warm temperate areas of Nepal. Karki et al. (2010) reported that Chhomrong dhan, Machhapuchre-3, Chandannath-1 and 
Chandannath-3 and Palung-2 have been adopted so far by farmers in Nepal as chilling tolerant cultivars. Chomrong rice of Nepal has become the most important variety in Bhutan and Madagascar covering around $85 \%$ of their rice area.

Barkat a cold tolerant variety in rice-rice rotation in mid altitude valleys of Bhutan was reported as early maturing variety (Ghimiray and Gurung, 1993). Endo et al. (2016) reported that a Bhutanese rice variety 'Kuchum' can be useful for developing a cold-tolerant variety. Some other cold tolerant varieties of Bhutan are Jakar Rey Naab, Khangma Maap, Yusi Rey Kaap1, Yusi Rey Kaap2, Yusi Rey Maap1, Yusi Rey Maap2 (Ghimiray et al., 2013). Neelima et al. (2015) reported that the rice genotypes Akshaydhan, Taramati, Bhadrakali, RNR 18805, RNR 17813 and WGL 44 were significantly superior to cold tolerant varieties Sheetal, Tellahamsa and JGL 3844 at Telangana in India. Some popular rice varieties grown in high elevation of India and Nepal are HPU1, Kanchan, Himali, Himdhan, Himalaya1, K332, Kalimpong1, Khonorullo and Meghalaya1 (Basuchaudhuri, 2014).

Basuchaudhuri (2014) reported that some varieties from China (B55, Banjiemang, Lijiangheigu and Yunlu 29), Japan (Jyoudeki), the USA (M103 and M104), Hungary (HSC55) and Australia (Quest) were tolerant or moderately tolerant to low temperature at booting and flowering stages. Three varieties from China (B55, Banjiemang and Lijiangheig) and one from Hungary (HSC55) showed consistent tolerance to low temperature at all growth stages. A temperate japonica variety TR22183, developed in northern China, is highly tolerant to low temperatures (Jiang et al., 2011). Some prominent cold tolerant rice varieties in Tohoku region of Japan are Ouu 415, Hitomebore, Ouu-PL 5, Iwate 100, Tohoku 207 and Tohoku PL 3 (Nakagomi, 2013). Sherpa a cold tolerant rice variety had higher spikelet fertility than the commercial cultivars Millin, Quest and Opus in a series of coldtolerance nurseries, and had spikelet fertility similar to that of the cold-tolerant standard varieties Baijieming and Jyoudeki (Reinke and Snell, 2011). Wang et al. (2013) reported that Jinbubyeo, Junganbyeo and SR30084-F8-156 from Korea, IR83222-f8-156 and IR83222-f8-14 from IKO showed cold tolerance with respect to grain fertility.

\section{Rice cold tolerance barrier in Bangladesh}

Cold injury of dry season irrigated Boro rice is a common problem for many areas in Bangladesh (BRRI, 2016). During Boro season, air temperature goes below critical temperature of rice especially in the northern part of this country (Figs. 1 and 2). Boro rice experienced very low temperature at seedling stage in December. In some cases, seed germination rate became low. Seedling got yellowish colour with insufficient growth. Farmers were not satisfied with their rice seedlings as they did not get quality seedlings from their seed bed. Seedling mortality occurred after transplanting. Sometimes transplanting was delayed by about two weeks. Some farmers have to buy seedling from market with high price (BRRI, 2016). Generally, Boro rice seeds are sown in seedbed in mid November, transplanted in main field in December and harvested from mid April to early May (BRRI, 2017). However, the farmers of haor areas (Sylhet, Sunamganj, Habiganj, Moulvibazar, Netrakona, Kishoreganj and Brahmanbaria) have to transplant Boro rice seedlings earlier than usual planting time to utilize early recession of residual flood water and also to avoid flash flood at the maturity (Biswas et al., 2008; Rashid and Yasmeen, 2017). Planting of Boro rice at usual time do not cause cold injury at reproductive stage in these areas, but crop has to encounter flash flood at maturity (Biswas et al., 2008). On the other hand, early transplanted Boro rice has every probability to face low temperature during February at reproductive phase that caused higher sterility (Fig. 2). Boro crop in the haor areas generally matures by the last week of April. Flash flood usually comes in these areas after 2nd week of April as Boishakhi Dhall (Biswas et al., 2008). Most of the farmers harvest their Boro rice by this time. But a flash flood by the 1st week of 

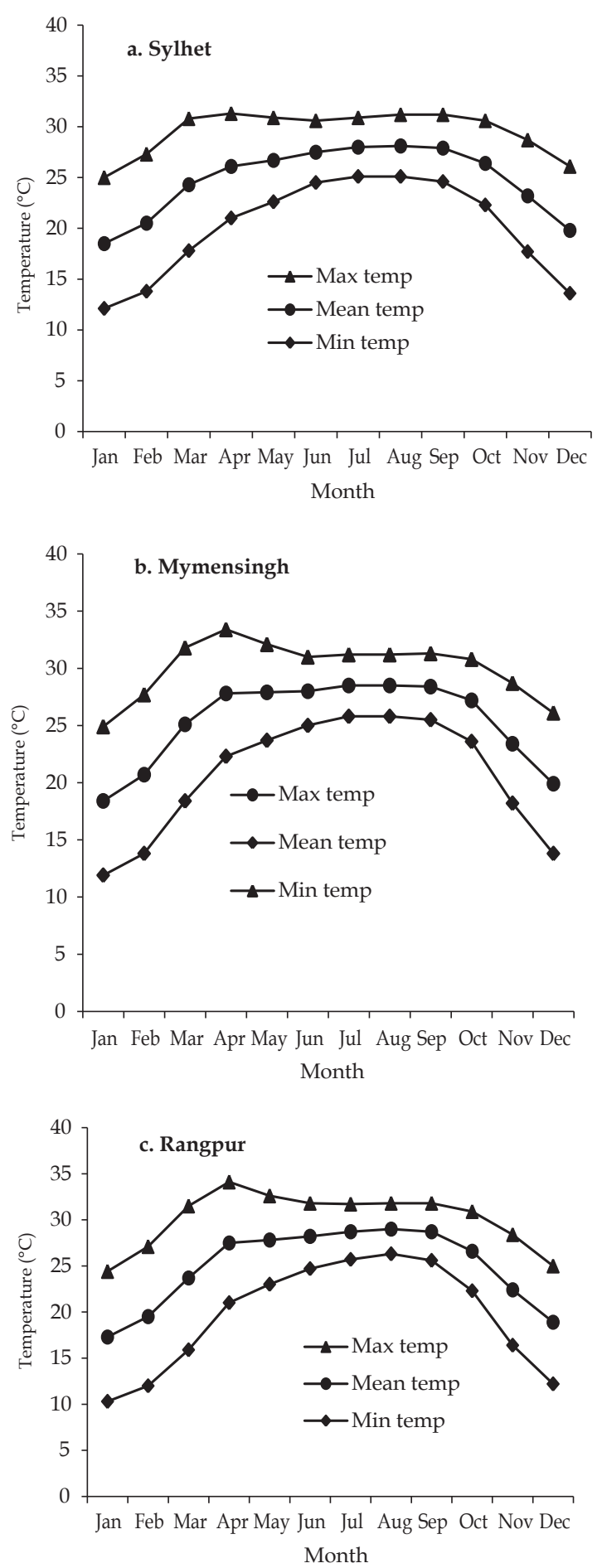

Fig. 1. Month wise maximum, minimum and mean air temperature at a. Sylhet, b. Mymensingh and c. Rangpur, Bangladesh (10-year-average).
April might affect many of the haor areas (Rashid and Yasmeen, 2017). Boro rice is submerged at premature stage, if flash flood occurs earlier (ie the 3rd or 4th week of March) as Chaitali Dhall, which causes an irreparable damage (Rashid and Yasmeen, 2017). However, early flash flood at premature stage of Boro rice during last week of March to 1st week of April is a rare event. An early flash flood has been devastated in March 2017. Premature Boro rice went under water in many parts of the haor areas that caused a huge disaster (Rashid and Yasmeen, 2017).

Analyzing the weather data of Sylhet region it is found that early flash flood was occurred in 1964, 1982, 1996, 2003, 2010 and 2017 from 1956 to till date (Fig. 3). According to Bangladesh Meteorological Department (BMD), the frequency of early flash flood is increasing. The haor areas of Bangladesh are sitting just below the downstream of the highest rainfall peak of the world (Cherapunji, Asam) has to face a blow of flash flood every year. Total rainfall for 5-6 days beyond $150 \mathrm{~mm}$ at the haor basin and its upstream is enough to cause a flood in these areas (Biswas et al., 2008). The rainfall in Sylhet region from 29 March to 3 April had been beyond $150 \mathrm{~mm}$ for six times in the years 1964, 1982, 1996, 2003, 2010 and 2017 since 1956 (Fig. 3). It was 156, 191, 153 and 265 $\mathrm{mm}$ in 1964, 1982, 2003 and 2010, respectively. In contrast, rainfall was $625 \mathrm{~mm}$ in March 2017, the highest ever and 10 times more than normal rainfall (Fig. 3). The rainfall of 2010 and 2017 can be considered as more severe. It has been observed that those abnormal rainfalls were at every seven years. However, the frequency of early flash flood might be closer in the years ahead due to global climate change.

To avoid early flash flood we have to harvest Boro rice by the last week of March. Then a crop will be safe against early flash flood. The growth duration of such variety must be within 130-135 days, if it is seeded and transplanted at usual time. Moreover, it should have some tolerance to cold at reproductive stage (Rashid and Yasmeen, 2017). Variety with such accommodative growth duration is not available in Boro season. Some local 

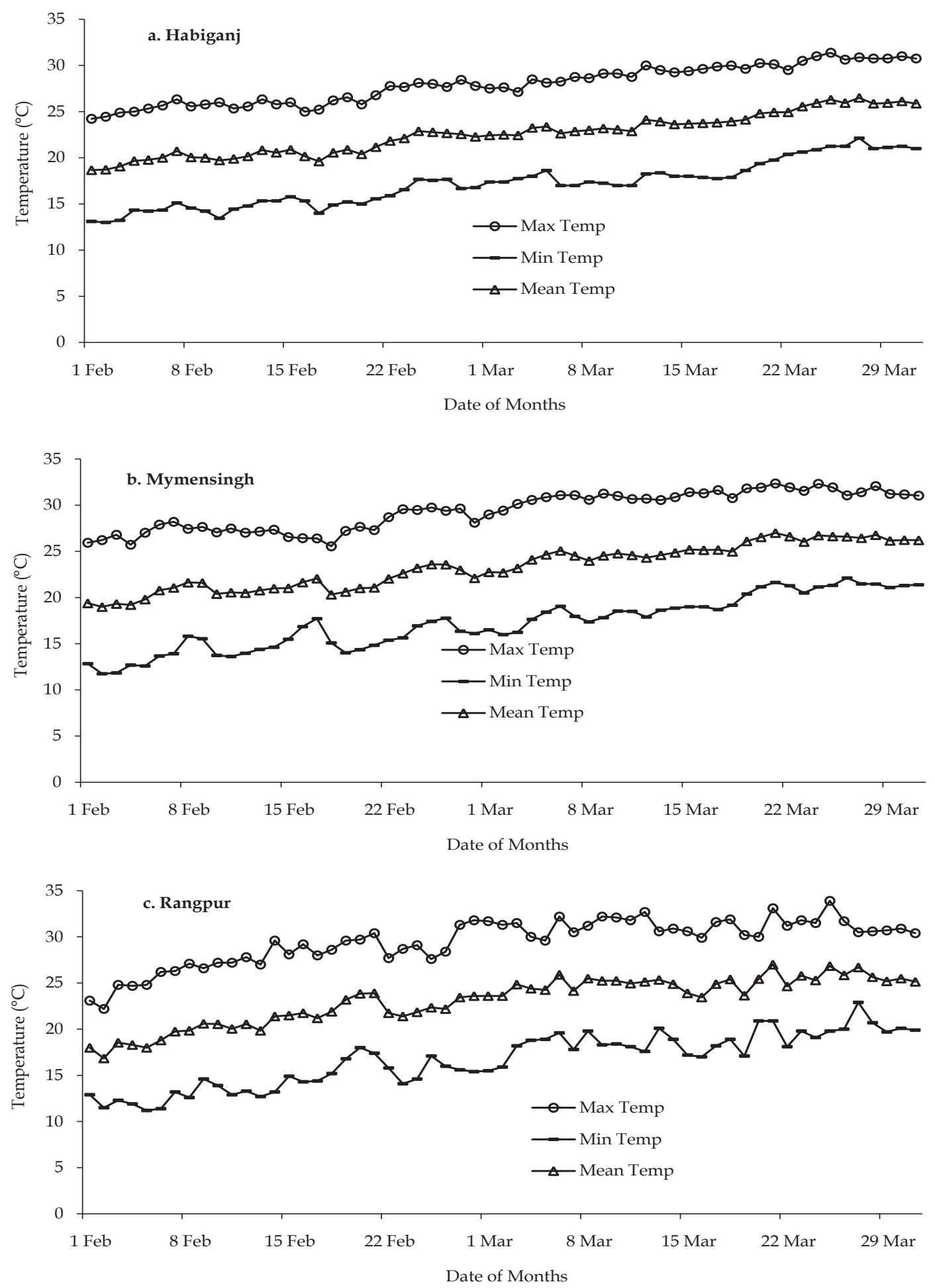

Fig. 2. Air temperature at - a. Habiganj, b. Mymensingh, c. Rangpur during February to March (10-year-average). 


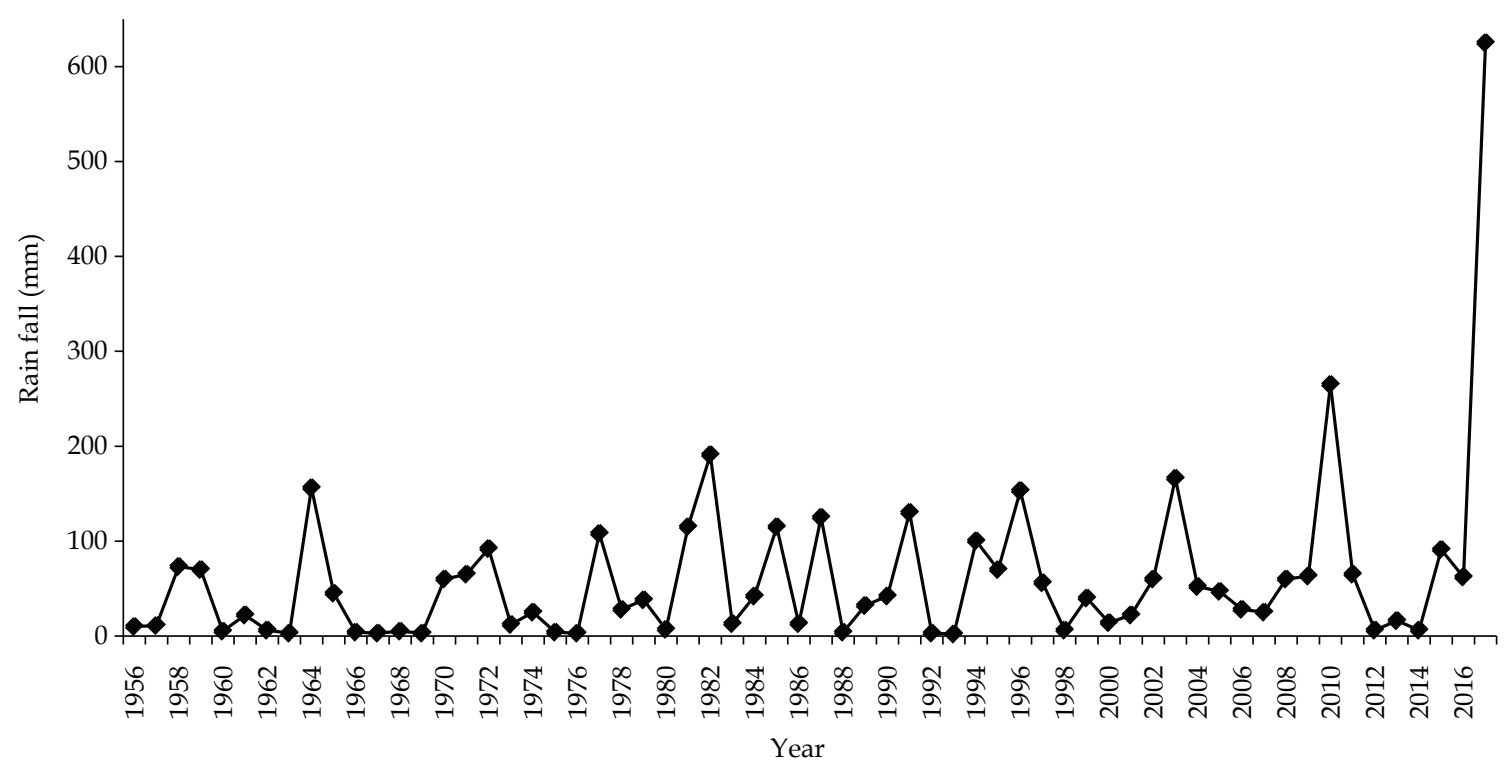

Fig. 3. Total rainfall in Sylhet from 29 March to 3rd April since 1956 to 2017.

improved varieties (LIV) like HbjB-IV and $\mathrm{HbjB}$-VI with 150 days growth duration cannot be accommodated under the stress of early flash flood. The best LIV could yield up to $3.0 \mathrm{t} / \mathrm{ha}$ during Boro season. Farmers like to cultivate the best yielding long duration (160 days) variety BRRI dhan 29 and they sow seeds in seedbed on first week of November or even last week of October. This crop matures at mid April (Table 2). Generally it did not face cold injury at reproductive stage due to its longer growth duration, but it has a high risk of flash flood at maturity (Table 2). Farmers of the haor areas do not prefer to cultivate another short duration Boro variety BRRI dhan 28 due its lower grain yield than BRRI dhan29. The growth duration of BRRI developed short duration Boro varieties (BRRI dhan28, BRRI dhan35, BRRI dhan36 and BRRI dhan45) is around 145 days, if recommended cultivation procedure is followed (BRRI, 2017). The appropriate seeding date of a 145-day-old variety (BRRI dhan28) is 15 November (BRRI, 2017). If 30-day-old seedling of this variety is transplanted, crop will be matured by 10 April (Table 2). It means even BRRI dhan28 with the shortest growth duration would not be able to avoid the early flash flood (Table 2).
However, theoretically we can say that any 145-day-variety seeded in 1 November on seedbed would be able to harvest by 25 March that could escape early flash flood. But practically it is not possible. It is observed that when 145-day-variety like BRRI dhan28 or BRRI dhan36 are sown in 1 November and transplanted in first week of December, the crop matures at about 3-4 April (Table 2). Therefore, sowing 15 days earlier than usual time increased the growth duration of these varieties by about a week (Table 2). Moreover, there is a chance of spikelet sterility if short duration variety like BRRI dhan 28 is sown in 1 November. So, we should not recommend for seeding of BRRI dhan 28 before 15 November. Recently, BRRI has identified moderate level of cold tolerance both at seedling and reproductive stages in a previously developed Boro variety BRRI dhan69. But its growth duration is around one week longer than BRRI dhan28. Sterility problem due to early planting can be minimized by using BRRI dhan69 for its reproductive stage cold tolerance. But, still there will be a risk of the early flash flood (Chaitali Dhall) for its longer growth duration (Table 2). 
Table 2. Planting time induced sterility and flash flood risk of Boro rice.

\begin{tabular}{|c|c|c|c|c|c|c|}
\hline Variety & $\mathrm{D} / \mathrm{S}$ & $\mathrm{D} / \mathrm{T}$ & PI & Flowering & Harvesting time & Risk \\
\hline \multirow[t]{2}{*}{$\begin{array}{l}\text { BRRI dhan28, } \\
\text { BRRI dhan36 }\end{array}$} & $1 \mathrm{Nov}$ & $\begin{array}{l}1^{\text {st }} \text { week of } \\
\text { Dec }\end{array}$ & $1^{\text {st }}$ week Feb (7 Feb) & $\begin{array}{l}1^{\text {st }} \text { week Mar } \\
(4 \text { Mar) }\end{array}$ & $\begin{array}{l}1^{\text {st }} \text { week Apr }(4 \\
\text { Apr) }\end{array}$ & $\begin{array}{l}\text { Spikelet sterility } \\
\text { Early flash flood }\end{array}$ \\
\hline & $15 \mathrm{Nov}$ & Mid Dec & $3^{\text {rd }}$ week Feb (16 Feb) & $\begin{array}{l}2^{\text {nd }} \text { week Mar } \\
(12 \text { Mar })\end{array}$ & $\begin{array}{l}2^{\text {nd }} \text { week Apr } \\
(10 \mathrm{Apr})\end{array}$ & Early flash flood \\
\hline \multirow[t]{2}{*}{ BRRI dhan29 } & $1 \mathrm{Nov}$ & Mid Dec & $4^{\text {th }}$ week Feb (24 Feb) & $\begin{array}{l}3^{\text {rd }} \text { week Mar } \\
(21 \text { Mar) }\end{array}$ & $\begin{array}{l}3^{\text {rd }} \text { week Apr (17 } \\
\text { April) }\end{array}$ & $\begin{array}{l}\text { Early flash flood } \\
\text { Normal flash } \\
\text { flood }\end{array}$ \\
\hline & $15 \mathrm{Nov}$ & $\begin{array}{l}3^{\text {rd }} / 4^{\text {th }} \text { week } \\
\text { Dec }\end{array}$ & $1^{\text {st }}$ week Mar (2-3 March) & $\begin{array}{l}1^{\text {st }} \text { week Apr } \\
(2 \mathrm{Apr})\end{array}$ & $\begin{array}{l}4^{\text {th }} \text { week Apr to } \\
1^{\text {st }} \text { week May }\end{array}$ & $\begin{array}{l}\text { Early flash flood } \\
\text { Normal flash } \\
\text { flood }\end{array}$ \\
\hline \multirow[t]{2}{*}{ BRRI dhan69 } & $1 \mathrm{Nov}$ & $\begin{array}{l}1^{\text {st }} \text { week of } \\
\text { Dec }\end{array}$ & $3^{\text {rd }}$ week Feb (15 Feb) & $\begin{array}{l}2^{\text {nd }} \text { week Mar } \\
\text { (13 Mar) }\end{array}$ & $\begin{array}{l}2^{\text {nd }} \text { week Apr } \\
(8 \text { April })\end{array}$ & Early flash flood \\
\hline & $15 \mathrm{Nov}$ & Mid Dec & $4^{\text {th }}$ week Feb (24 Feb) & $\begin{array}{l}3^{\text {rd }} \text { week Mar } \\
\text { (20 Mar) }\end{array}$ & $\begin{array}{l}3^{\text {rd }} \text { week Apr (17 } \\
\text { Apr) }\end{array}$ & $\begin{array}{l}\text { Early flash flood } \\
\text { Normal flash } \\
\text { flood }\end{array}$ \\
\hline
\end{tabular}

Mitigation of rice cold injury and flash flood damage

Cultivation of cold tolerant Boro rice varieties is the most appropriate solution to overcome rice cold injury. However, at present we have a few cold tolerant varieties in Bangladesh. BRRI dhan36 has some tolerance to cold but not enough to satisfy farmer. Unfortunately, farmers did not accept this variety. Recently BRRI has identified moderate level of cold tolerance both at seedling and reproductive stages in a previously developed Boro variety BRRI dhan69. Until we have appropriate cold tolerant varieties for Boro season, we have to put emphasis on cultural practices to mitigate cold tolerance. Mahbub et al. (2008) reported that Boro seedbed could be covered with transparent polythene sheet at daytime from 10-11 am to sunset for raising healthy seedlings during cold spell. It increases temperature inside polythene cover and ultimately provides better seedling growth. Water management is an important issue for mitigating rice cold injury. Deep watering, round channels and polyethylene tubes around the field can increase water temperature. Use of deep irrigation (20$25 \mathrm{~cm}$ ) during the reproductive period might help to insulate the crop against low-minimum temperature events (Reinke and Snell, 2011). When the air temperature is low enough to damage rice crops at panicle initiation or early booting, deepwater irrigation $(15-20 \mathrm{~cm})$ is an effective way of protecting panicle formation and increasing filled-grain ratio (NYAES, 1993).

Nutrient content in rice plant is an important issue during cold conditions. At low temperature condition during booting, nitrogen concentration in plant should be low. Risk of yield reduction in a cool weather is greatly enhanced by increased $\mathrm{N}$ status of crop (Amano, 1984). Top dressing of $\mathrm{N}$ at flagleaf stage during lower temperatures increases the risk of damage to rice crop. Phosphorus is an important nutrient in mitigation of cold injury (Lee et al., 1987). Low temperature damage is reduced when sufficient phosphate is applied in rice plant (RDA, 1981). Organic matter application can improve physical and chemical properties of soil, which may reduce cold damage by increasing water and fertilizer holding capacities in rice field. Amano (1984) showed that applications of compost improved root health and minimized cool weather damage in Japan through reducing spikelet sterility.

Chemical treatments of chilling-sensitive plants lead to increase chilling tolerance. Foliar application of osmoprotectants (spermine and glycinebetaine) offered significant cold tolerance by reducing spikelet sterility in rice cultivars (Zhao et al., 1992; Naidu and Williams, 2004). Chen et al. (2005) reported that seed treatment 
with gibberellic acid and glycinebetaine improves seedling emergence and seedling vigour of rice under low temperature. Exogenous application of abscisic acid (ABA) induced some levels of freezing tolerance in chilling sensitive rice seedlings (Shinkawa et al., 2013). Cellular and genetic engineering is a new trend, which allows fundamental changes in the chilling resistance of chilling-sensitive plants. GMO rice plant with trehalose producing genes improves tolerance to drought, salt and low temperature (Wu and Garg, 2003).

For escaping Boro rice crop from flash flood submergence at the haor areas of Bangladesh we have to develop Boro rice varieties having growth duration of 130-135 days with reproductive stage cold tolerant. Then rice crop might be safe against early flash flood through earlier harvesting. However, there are some alternatives by which we can harvest Boro rice earlier in the haor areas. Double transplanting would be a better option for harvesting one week earlier. In this method of cultivation, rice seeds are to be sown in seedbed on 1 November followed by first transplanting with closer spacing $(10 \mathrm{~cm} \times 10 \mathrm{~cm})$ in first week of December at upper parts of the land and finally double transplanting with usual spacing (20 $\mathrm{cm} \times 20 \mathrm{~cm}$ ) in mid January at lower basins. Manipulation of seedling age could be an alternative option to reduce growth duration. If we transplant 30-day-old seedlings instead of 45-day-old seedlings of same seedbed, the growth duration will be reduced by around a week (Biswas et al., 2008). Another alternative could be growing of seedling under polythene shade.

Higher temperature at seedling stage under the shade might compensate some degree-day to reduce its growth duration to some extent. Direct seeding is a way to reduce growth duration by about one week. Sowing sprouted seeds in puddle or zero tillage fields would be a better option. In this method, harvesting could be earlier, but the field duration would be increased. The applicability of all these practices largely depends on the farmer's preference. More importantly, the farmers of the haor areas should cultivate short duration Boro varieties (BRRI dhan28, BRRI dhan36, BRRI dhan45, BRRI dhan74, BRRI hybrid dhan3 and BRRI hybrid dhan5) rather than only long duration variety. They have to sow seeds on 15 November and transplant 30-35-day-old seedlings in the main field.

\section{CONCLUSIONS}

Cold stress is one of the major abiotic stresses reducing rice production especially in regions where the indica subspecies is cultivated. In Bangladesh, Boro rice seedlings are damaged at seedbed and also after transplanting in December to January, while early planted Boro rice is affected by cold injury at reproductive stage in February. The use of cold tolerant varieties and implementation of appropriate cultural practices are important for minimizing low temperature damage. Moreover, we have to establish the optimum seeding and transplanting time of rice based on minimum, mean and maximum temperatures at different regions with appropriate rice varieties to minimize rice cold injury. Boro rice varieties with shorter growth duration (130 to 135 days), higher yield and tolerant to low temperature at reproductive stage with some desirable traits to the farmer are earnestly needed in the haor areas of Bangladesh. Some cold tolerant genotypes are available in different countries. We could collect and use those genotypes in our varietal development programme. Until we develop desired cold tolerant short duration variety, we could try some of the cultural practices able to shorten the growth duration for harvesting earlier in haor areas.

- Cultivation of existing short duration high yielding varieties (BRRI dhan28, BRRI dhan36, BRRI dhan45, BRRI dhan81, BRRI dhan84, BRRI hybrid dhan3 and BRRI hybrid dhan5) instead of long duration variety BRRI dhan29.

- Sowing seeds of short duration Boro varieties on 15 November and transplanting 30-35- day-old seedlings in main field. 
- Seedling raising under polythene shade to compensate degree day for reducing growth duration.

- Early harvesting (around a week) by using direct seeded rice or manipulation of seedling age or double transplanting method of cultivation.

\section{REFERENCES}

AIS. 2016. Krishi Diary 2016, Agricultural Information Service, Khamarbari, Farmgate, Dhaka-1215, Bangladesh.

Alvarado, R and S Hernaiz. 2007. Antecedentes Generales Sobre el Arroz en Chile. In: Alvarado R (ed.) Arroz. Manejo tecnológico. Boletín INIA $N^{\circ} 162.179$ p. Instituto de Investigaciones Agropecuarias INIA, Centro Regional de Investigación Quilamapu, Chillán, Chile.

Amano, T. 1984. Studies on cool weather damage with special reference to improvement in rice cultivation technique. Report of the Hokkaido Prefecture Agricultural Experiment Station, 46, 1-67.

Andaya, V and D Mackill. 2003. Mapping of QTLs associated with cold tolerance during the vegetative stage in rice. J. Exp. Bot. 54: 2579-2585.

Basuchaudhuri, P. 2014. Cold Tolerance in Rice Cultivation. CRC Press Taylor and Francis Group, Boca Raton, FL. 200p.

BER, (Bangladesh Economic Review). 2015. Bangladesh Economic Review 2015. Ministry of Finance, Government of the People's Republic of Bangladesh, Bangladesh Secretariat, Bangladesh.

Biswas, J K, M A A Mahbub and M S Kabir. 20011. Critical temperatures and their probabilities on important growth stages of rice. In: Bashar M K, J C Biswas and M A Kashem (eds) Annual Report of Bangladesh Rice Research Institute, 2008-2009, BRRI, Gazipur-1701. pp127-129.

Biswas, J K, M S Hossain, M S I Mamin and M A Muttaleb. 2008. Manipulation of seeding date and seedling age to avoid flash flood damage of Boro rice at the Northeastern haor area of Bangladesh. Bangladesh Rice J. 13: 57-61.

Brolley, M. 2015. Rice security is food security for much of the world. Rice Today. International Rice Research Institute (IRRI), DAPO Box 7777, Metro Manila, Philippines. pp 30-32.

BRRI, (Bangladesh Rice Research Institute). 2016. BRRI Annual Research Review Report for 2015-2016. Plant Physiology Division. Bangladesh Rice Research Institute, Gazipur-1701. (data unpublished)
BRRI, (Bangladesh Rice Research Institute). 2017. Adhunik Dhaner Chash (Cultivation of Modern Rice) Bangladesh Rice Research Institute, Gazipur-1701.

Chen, D, T A Gunawardena, B P Naidu, S Fukai and J Basnayake. 2005. Seed treatment with gibberellic acid and glycinebetaine improves seedling emergence and seedling vigour of rice under low temperature, Seed Sci. Technol. 33: 471-479.

Cruz, R P and S C K Milach. 2004. Cold temperature tolerance at the germination stage of rice: Methods of evaluation and characterization of genotypes. Sci. Agric. 61: 1-8.

Cruz, R P, R A Sperotto, D Cargnelutti, J M Adamski, T F Terra and J P Fett. 2013. Avoiding damage and achieving cold tolerance in rice plants. Food Energy Secur. 2: 96-119.

Cruz, R P, S C K Milach and L C Federizzi. 2006. Rice cold tolerance at reproductive stage in a controlled environment. Sci. Agric. 63: 255-261.

Dingyuan, F and F Liqun. 1989. Main metrological problems of rice production and protective measures in Chaina. Int. J. Boimeteorol. 33: 1-6.

Dingyuan, F and F Liqun. 1989. Main meteorological problems of rice production and protective measures in China. Int. J. Biometeorol. 33: 1-6.

Endo, T, B Chiba, K Wgatsuma, K Saeki, T Ando, A Shomura, T Mizubayashi, T Ueda, T Yamamoto and T Nishio. 2016. Detection of QTLs for cold tolerance of rice cultivar 'Kuchum' and effect of QTL pyramiding. Theor. Appl. Genet. 129: 631-40.

Fairhurst, T and A Dobermann. 2002. Rice in the global food supply. Better Crops Int. 16: 3-6.

Farrell, T C, K M Fox, R L Williams and S Fukai. 2006. Genotypic variation for cold tolerance during reproductive development in rice: Screening with cold air and cold water. Field Crops Res. 98: 178-194.

Gautam, A K and N P Shrestha. 2012. Temperate japonica rice in Nepal. In: Jena $\mathrm{K} \mathrm{K}$ and B Hardy (eds) Advances in Temperate Rice Research. International Rice Research Institute, Los Baños, Philippines. pp 49-57.

Gautam, S, H K Panta, M L Velasco, Y N Ghimire, D Gauchan and S Pandey. 2013. Tracking of improved rice varieties in Nepal. Country report for the project Tracking of Improved Varieties in South Asia. IRRI monograph, International Rice Research Institute, Los Baños, Philippines.

Ghimiray, M and T R Gurung. 1993. Barkat a cold tolerant variety for the first crop in rice-rice rotations in mid altitude valleys of Bhutan. IRRN. 18: 35-35.

Ghimiray, M, S Pandey and M L Velasco. 2013. Tracking of improved rice varieties in Bhutan. Country report for the project Tracking of Improved Varieties 
in South Asia. IRRI monograph, International Rice Research Institute, Los Baños, Philippines.

Ghimiray, M. 2012. Temperate japonica rice in Bhutan. In: Jena K K and B Hardy (eds) Advances in Temperate Rice Research. International Rice Research Institute, Los Baños, Philippines. pp15-25.

Heenan, D P. 1984. Low-temperature-induced floret sterility in the rice cultivars Calrose and Inga as influenced by nitrogen supply. Aust. J. Exp. Agric. 24: 255-259.

Jacobs, B C and C J Pearson. 1994. Cold damage and development of rice: a conceptual model. Australian J. Exp. Agri. 34: 917-919.

Jena, K K, S M Kim, J P Suh, C I Yang and Y J Kim. 2012. Identification of cold-tolerant breeding lines by quantitative trait loci associated with cold tolerance in rice. Crop Sci. 51: 517-523.

Jiang, W, Y M Jin, J Lee, K L Lee, R Piao, L Han, J C Shin, R D Jin, T Cao, H Y Pan, X Du and H J Koh. 2011. Quantitative trait loci for cold tolerance of rice recombinant inbred lines in low temperature environments. Mol. Cells. 32: 579-587.

Karki, T B, K B Koirala and S B BK. 2010. Participatory variety selection of cold tolerant rice in the western hills of Nepal. Agron. J. N. 1: 74-79.

Kim, S I and T H Tai. 2011. Evaluation of seedling cold tolerance in rice cultivars: a comparison of visual ratings and quantitative indicators of physiological changes. Euphytica. 178: 437-447.

Kumari, S, V P N Sabharwal, H R Kushwaha, S K Sopory, S L Singh-Pareek and A Pareek. 2009. Transcriptome map for seedling stage specific salinity stress response indicates a specific set of genes as candidate for saline tolerance in Oryza sativa L. Funct. Integr. Genom. 9: 109-123.

Lee, M H, Y J Oh, J H Lee and Y S Ham. 1987. Physiological relationship between nitrogen fertilizer and cold tolerance at low temperature of rice plant. Research Report on Phytotron Experiment, II. Suwon, Korea, National Crop Experiment Station, pp 60-69.

Lee, M H. 2001. Low temperature tolerance in rice: The Korean experience. In: Fukai S and J Basnayake (eds) Increased lowland rice production in the Mekong Region. Proceedings of an international workshop, Vientiane, Laos, 30 October to 2 November 2000. Australian Center for International Agricultural Research, Canberra, Australia. pp 109-117.

Mackill, D J, W R Coffman and D P Garrity. 1996. Rainfed lowland rice improvement. International Rice Research Institute, Manila. 242p.

Mahajan, S and N Tuteja. 2005. Cold, salinity and drought stresses: An overview. Arch. Biochem. Biophys. 444: 139-158.

24 Rashid and Yasmeen
Mahbub, M A A, J K Biswas, R Yasmeen and M A Haque. 2008. Effect of polyethylene cover on quality rice seedling production during winter season. Bangladesh Rice J. 14: 15-26.

Naidu, B P and R Williams. 2004. Seed treatment and foliar application of osmoprotectants to increase crop establishment and cold tolerance at flowering in rice. A Report of the Rural Industries Research and Development Corporation Project No. CST2A. Brisbane: CSIRO Tropical Agriculture.

Nakagomi, K. 2013. Selection of new check rice varieties for evaluating high cold tolerance and the development of breeding lines with high cold tolerance in the Tohoku region of Japan. JARQ. 47: 1-7.

Nath, N C. 2015. Food security in Bangladesh: Status, challenges and strategic policy options. Paper presented at 19th Biennial Conference of the Bangladesh Economic Association (BAE), held on 8-10 January, 2015, Dhaka, Bangladesh.

Neelima, P, K J Rani, C D Raju and K Keshavulu. 2015. Evaluation of rice genotypes for cold tolerance. Agric. Sci. Res. J. 5: 124-133.

NYAES (National Yeongnam Agricultural Experiment Station). 1993. Annual Research Report (Rice). Milyang, Korea.

Peyman, S and A Hashem. 2010. Evaluation eighteen rice genotypes in cold tolerant at germination stage. World Appl. Sci. J. 11: 1476-1480.

Rashid, M M and R Yasmeen. 2017. Rice cultivation in haor: Ways to avoid cold injury and flood risk. BRRI Newsletter, July-September 2017. Bangladesh Rice Research Institute, Gazipur-1701.

RDA (Rural Development Administration). 1981. Report of low temperature damage in 1980 and its comprehensive technological counter measures of rice. Suwon, Korea.

Reinke, R and P Snell. 2011. Registration and description of rice variety Sherpa. Plant Var. J. 24: 219-223.

Reinke, R, G Beecher, B Dunn and P Snell. 2012. Temperate rice in Australia. In: Jena K K and B Hardy (eds) Advances in Temperate Rice Research. International Rice Research Institute, Los Baños, Philippines. pp 1-14.

Sanghera, G S, S H Wani, W Hussain and N B Singh. 2011. Engineering cold stress tolerance in crop plants. Curr. Genomics. 12: 30-43.

Satake, T, S Y Lee, S Koike and K Kariya. 1987. Male sterility caused by cooling treatments at the young microspore stage in rice plants. XXVII. Effect of water temperature and nitrogen application before the critical stage on the sterility induced by cooling at the critical stage. Jpn. J. Crop Sci. 56: 404-419. 
Satake, T. 1976. Sterility-type cold injury in paddy rice plants. In: Proceedings of the symposium on climate and rice. IRRI, Los Baños, Philippines, pp 281-300.

Sharifi, P. 2010. Evaluation on sixty-eight rice germplasms in cold tolerance at germination stage. Rice Sci. 17: 77-81.

Shelton, A M, J Z Zhao and R T Roush. 2002. Economic, ecological, food safety, and social consequences of the deployment of Bt transgenic plants. Annu. Rev. Entomol. 47: 845-881.

Shimono, H, M Okada, E Kanda and I Arakawa. 2007. Low Temperature induced sterility in rice: Evidence for the effects of tmperature before panicle initiation. Field Crops Res. 101: 221-231.

Shinkawa, R, A Morishita, K Amikura, R Machida, H Murakawa, K Kuchitsu and M Ishikawa. 2013. Abscisic acid induced freezing tolerance in chillingsensitive suspension cultures and seedlings of rice. BMC Research Notes. 6:351. https://doi. org/10.1186/1756-0500-6-351.

Singh, B K, M Sutradhar, A K Singh and N Mandal. 2017. Cold stress in rice at early growth stage - An overview. Int. J. Pure App. Biosci. 5: 407-419.

Smillie, R, S E Hetherington, J Hie and R Nott. 1988. Photo inhibition at chilling temperatures. In: Evans J R, S V Caemmerer and WWA III (eds) Ecology of photosynthesis in sun and shade. CSIRO: East Melbourne. pp 207-222.

Sthapit, B R. 1992. Chilling injury of rice crop in Nepal: a review. J. Inst. Agric. Anim. Sci. 13: 1-32.

Subudhi, P K, T Sasaki, G S Khush. 2006. Rice. In: Kole C (ed.) Genome Mapping and Molecular Breeding in Plants. Vol. 1, Cereals and Millets. Springer-Verlag Berlin Heidelberg. pp. 1-78.
Tao, F, S Zhang and Z Zhang. 2012. Changes in rice disasters across China in recent decades and the meteorological and agronomic causes. Reg. Environ. Change. 13: 743-759. doi: 10.1007/s10113-012-0357-7.

Vij, S and A K Tyagi. 2007. Emerging trends in functional genomics of abiotic response in crop plants. Plant Biotech. J. 5: 361-380.

Wang, J, X Lin, Q Sun and K K Jena. 2013. Evaluation of cold tolerance for japonica rice varieties from different country. Adv. J. Food Sci. Technol. 5: 54-56.

$\mathrm{Wu}, \mathrm{R}$ and A Garg. 2003. Engineering rice plant with trehalose producing genes improves tolerance to drought, salt and low temperature. ISB news report, March 2003. Covering agricultural and environmental biotechnology developments. ISB News Report, February.

Xie, G, H Kato and R Imai. 2012. Biochemical identification of the OsMKK6-OsMPK3 signaling pathway for chilling stress tolerance in rice. Biochem. J. 443: 95-102.

Xu, L M, L Zhou, Y W Zeng, F M Wang, H L Zhang, S Q Shen and Z C Li. 2008. Identification and mapping of quantitative trait loci for cold tolerance at the booting stage in a japonica rice near-isogenic line. Plant Sci. 174: 340-347.

Ye, C, S Fukai, D I Godwin, R Reinke, P Snell, J Schiller and J Basnayake. 2009. Cold tolerance in rice varieties at different growth stages. Crop Pasture Sci. 60: 1-11.

Yoshida, S. 1981. Fundamentals of rice crop science. International Rice Research Institute, Los Baños, Philippines. pp 1-63.

Zhao, Y, D Aspinall and L G Paleg. 1992. Protection of Membrane Integrity in Medicago sativa L by Glycinebetaine against the Effects of Freezing. J. Plant Physiol. 140: 541-543. 
